\title{
Lack of Evidence of Vertical Transmission of 'Candidatus Liberibacter solanacearum' by Carrot Seeds Suggests That Seed is not a Major Transmission Pathway
}

\author{
Marianne Loiseau, ${ }^{\dagger}$ Isabelle Renaudin, Pascaline Cousseau-Suhard, Pierre-Marie Lucas, Aurélie Forveille, and Pascal Gentit, ANSES- \\ Laboratoire de la Santé des Végétaux, 49044 Angers Cedex 01, France
}

\begin{abstract}
'Candidatus Liberibacter solanacearum' is a bacterium associated with several vegetative disorders on solanaceous and apiaceous crops. Following the recent detection of the bacterium in carrots in Europe, and particularly carrot plants used for seed production in France, two independent laboratories conducted experiments on the transmission of this pathogen by seed and had discordant results: one study showed no bacterial transmission to plants, and the other showed transmission to carrot seedlings starting from the fourth month of culture. To test the hypothesis that growing conditions affect seed transmission efficiencies, trials were renewed in 2015 on four lots of 500 carrot seeds naturally

contaminated with ' $\mathrm{Ca}$. L. solanacearum' and two lots of 100 healthy seeds. The plants were grown for 6 months in an insect-proof NS2 greenhouse. Sets of 108 plants from the contaminated lots and 24 plants from the healthy lots were individually analyzed each month using realtime PCR to detect the bacterium. The detection tests on seeds and plants from healthy lots were always negative. During the 6 months of the trial, no plants from the contaminated seed lots tested positive for the bacterium or showed any infection symptoms. These results indicate that transmission of ' $\mathrm{Ca}$. L. solanacearum' by carrot seed is rare and difficult to reproduce.
\end{abstract}

'Candidatus Liberibacter solanacearum', a gram-negative bacterium belonging to the class Alphaproteobacteria, is phloem-limited plant pathogen that cannot yet be cultured in vitro (Bové 2006; Jagoueix et al. 1994; Liefting et al. 2009b). Since 2009, this bacterium has been associated with an economically important disease in potato (Solanum tuberosum L.) called "zebra chip" (Secor et al. 2009), which is emerging in the United States and New Zealand. It is also associated with diseases in other solanaceous crops such as tomato (Solanum lycopersicon), pepper (Capsicum annum), eggplant (Solanum melongena), tomatillo (Physalis peruviana), tamarillo (Solanum betacenum), tobacco (Nicotiana tabacum), and several solanaceous weeds (Munyaneza 2015). The bacterium is now widespread in the southwestern, central, and northwestern United States, Mexico, Central America, and New Zealand, where zebra chip has caused millions of dollars in losses to the potato industry. In Europe, ' $\mathrm{Ca}$. L. solanacearum' has been associated with yellow decline and vegetative disorders in some apiaceous crops, including carrots (Daucus carota L.) (Munyaneza et al. 2010b), celery (Apium graveolens) (Teresani et al. 2014), chervil (Anthriscus cerefolium), fennel (Foeniculum vulgare), parsley (Petroselinum crispum), and parsnip (Pastinaca sativa) (Hajri et al. 2017). Damage to apiaceous crops has been reported to cause up to $100 \%$ crop loss (Munyaneza et al. 2010b). In Europe, the bacterium has been reported from Finland, Norway, Sweden (Munyaneza et al. 2010a; Munyaneza et al. 2012b; Munyaneza et al. 2012c), Spain, and the Canary Islands (Alfaro-Fernández et al. 2012a; Alfaro-Fernández et al. 2012b), France (Loiseau et al. 2014), Austria (EPPO 2015), and Germany (Munyaneza et al. 2015). It has also been identified on carrot in Morocco and Israel (EPPO 2017; Tahzima et al. 2014).

To date, five haplotypes of ' $\mathrm{Ca}$. L. solanacearum' have been described (Nelson et al. 2011; Nelson et al. 2013; Teresani et al. 2014). Haplotypes $\mathrm{A}$ and $\mathrm{B}$ are associated with diseases of solanaceous plants in the Americas and New Zealand, whereas the other three haplotypes (C, D, and E) are associated with diseases of apiaceous plants in northern Europe and the Mediterranean region.

Like other liberibacters, ' $C a$. L. solanacearum' is transmitted by psyllid vectors and by grafting (Secor et al. 2009). In the geographical

${ }^{\dagger}$ Corresponding author. E-mail address: marianne.loiseau@anses.fr

Accepted for publication 20 June 2017.

() 2017 The American Phytopathological Society region where the bacterium is known to infect solanaceous plants, the psyllid vector is Bactericera cockerelli (Sulc) (Munyaneza et al. 2007; Secor et al. 2009). In apiaceous crops, ' $\mathrm{Ca}$. L. solanacearum' is transmitted to healthy plants by the psyllids Trioza apicalis in northern Europe (Munyaneza et al. 2010a; Nissinen et al. 2014) and Bactericera trigonica in the Mediterranean region (Alfaro-Fernández et al. 2012b; Tahzima et al. 2017). In potato, this bacterium can also be transmitted from mother tubers to daughter plants and to progeny tubers (Pitman et al. 2011); however, infected tubers produce weak plants that die prematurely. Therefore, the transmission of ' $\mathrm{Ca}$. L. solanacearum' by infected seed tubers is epidemiologically negligible (Munyaneza 2012). For solanaceous plants, ' $C a$. L. solanacearum' does not appear to be transmitted by true seeds from infected plants (Munyaneza 2012).

The recent reports of ' $\mathrm{Ca}$. L. solanacearum' in carrot and celery in various European countries and North Africa have raised the question of the source of inoculum. Teresani et al. (2014) suggest that ' $\mathrm{Ca}$. L. solanacearum' is transmitted vertically through seed. Indeed, carrot crops are propagated by true seeds that are known to transmit various pathogens (Noble 1957). Two previous studies were conducted in two independent laboratories to assess potential transmission of ' $\mathrm{Ca}$. $\mathrm{L}$. solanacearum' by carrot seed. The same three lots of seed, collected in France and naturally contaminated by ' $\mathrm{C} a$. L. Solanacearum', were used in both studies. In one study, the bacterium was found to be transmitted by seeds after cultivation of carrots in greenhouse for 5 months with a transmission rate ranging between 12 and 42\% (Bertolini et al. 2015). In the other study, no bacterial transmission by seed was observed after cultivation of carrots for 9 months in greenhouse, including an interruption of 4 months of overwintering conditions (Loiseau et al. 2017). This discrepancy may be related to different agro-climatic growing conditions.

To further elucidate potential vertical transmission of ' $\mathrm{Ca}$. L. solanacearum' by carrot seeds, we conducted an additional study in 2015 using new naturally contaminated seeds in temperate environmental conditions equivalent to those used by Bertolini et al. (2015)

\section{Materials and Methods}

Plant materials. The carrot seed lots were selected from naturally ' $C a$. L. solanacearum' contaminated seeds produced in 2014 in France (Table 1). Lots used for the assay were selected based on the following criteria: a contamination rate greater than $93 \%$, a minimum of 760 viable ' $\mathrm{Ca}$. L. solanacearum' per gram of seeds, a good germination rate, and no contamination by seed-transmitted pathogens. The carrot seed lots were tested for germination and contamination with Alternaria 
dauci, A. radicina following the rules of the International Seed Testing Association, and Xanthomonas hortorum pv. carotae using real-time PCR with primers described by Meng et al. (2004). Carrot seed lots free of ' $\mathrm{Ca}$. L. solanacearum' were also included (lot nos. TS1 and TS2).

DNA purification. For seeds, total DNA was purified using a modified CTAB (cetyltrimethyl ammonium bromide) protocol (Murray and Thompson 1980). One gram of seeds was ground in a plastic bag (Bioreba AG, Basel, Switzerland) with a pneumatic press in $10 \mathrm{ml}$ of CTAB buffer $3 \%$. A subsample of $1 \mathrm{ml}$ of the ground sample was transferred to an Eppendorf tube and mixed with $2 \mu$ l of $\beta$-mercaptoethanol (final concentration at $0.2 \%$ ) and incubated for $20 \mathrm{~min}$ at $65^{\circ} \mathrm{C}$. After incubation, an equal volume of chloroform:isoamyl alcohol (24:1) was added. Samples were vortexed, centrifuged at $10,000 \mathrm{~g}$ for $10 \mathrm{~min}$, and $750 \mu \mathrm{l}$ of the aqueous layer was transferred to a new microtube containing $750 \mu \mathrm{l}$ of cold isopropanol. DNA was recovered by centrifugation at 10,000 $\mathrm{g}$ for $15 \mathrm{~min}$. The pellet was washed with ice-cold $90 \%$ ethanol and centrifuged at 10,000 g for $10 \mathrm{~min}$. After removal of ethanol, the pellet was air-dried then resuspended in $100 \mu$ l nucleasefree water.

For carrot plant petioles, total DNA was purified using the DNeasy Plant Mini kit (Qiagen, Valencia, CA, USA). One gram of petioles was ground in a plastic bag (Bioreba AG, Basel, Switzerland) with a pneumatic press in $10 \mathrm{ml}$ of PBS buffer. The further extraction steps of DNA were done according to the manufacturer's instructions.

Positive and negative controls were used in each extraction. The positive control consists in $1 \mathrm{~g}$ of carrot naturally contaminated by ' $C a$. L. solanacearum' while the negative control consists in $1 \mathrm{~g}$ of carrot free of these bacteria. Purified DNAs were stored at $-20^{\circ} \mathrm{C}$ until use.

Real-time PCR. Real-time PCR assays were performed using a ' $C a$. L. solanacearum' specific LsoF forward primer and HLBr reverse primer and the liberibacter-universal TaqMan probe HLBp (Li et al. 2009), using a MxPro3005 thermal cycler (Agilent Technologies, Santa Clara, CA, USA). The reaction mix consisted of 1× TaqMan Universal MasterMix, No Amperase UNG master mix (Applied Biosystems, Foster City, CA, USA), $240 \mathrm{nM}$ of each LsoF and HLBr primers, $120 \mathrm{nM}$ of HLBp probe and $5 \mu \mathrm{l}$ of the template (pure DNA and 1:10 dilution in nuclease-free water) in a final reaction volume of $25 \mu$ l. Positive and negative controls were used in each PCR reaction. The positive control consisted of a total DNA extract from a carrot naturally contaminated by ' $\mathrm{Ca}$. L. solanacearum' and the negative control consisted of DNase-free water. The real-time PCR amplification protocol consisted of $95^{\circ} \mathrm{C}$ for $10 \mathrm{~min}$ followed by 45 cycles of $95^{\circ} \mathrm{C}$ for $15 \mathrm{~s}$ and $60^{\circ} \mathrm{C}$ for $1 \mathrm{~min}$. Data acquisition and analysis were performed using the thermal cycler's software.

Estimation of the contamination rate of carrot seed lots. To calculate the contamination rate of the carrot seed lots used in the study, the statistical method of the most probable number (MPN) was used (Swaroop 1951). For each lot, five subsamples of one seed, five subsamples of 10 seeds, and one subsample of 50 seeds were analyzed using real-time PCR. To confirm the results obtained with the MPN approach, 50 seeds were analyzed individually for each seed lot.

Quantification of ' $\mathrm{Ca}$. L. solanacearum'. To generate a standard curve, an amplified real-time PCR product was obtained using the primers LsoF and HLBr (Li et al. 2009). This product was cloned using the TOPO TA Cloning Kit for sequencing (Life Technologies, Carlsbad, CA, USA). Tenfold serial dilutions of the transformed bacteria were prepared from $1.10^{-1}$ to $1.10^{-6}$ and stored at $-20^{\circ} \mathrm{C}$ until use. Dilutions were plated to count the population of bacteria and three repetitions of each dilution were amplified using real-time PCR (Li et al. 2009). There are three copies of the 16S RNA gene in the ' $\mathrm{Ca}$. L. solanacearum' genome; therefore, the quantification obtained with this standard curve is divided by three to determine the number of bacteria in the tested seed lots. Viable ' $\mathrm{Ca}$. L. solanacearum' cells were quantified using the propidium monoazide (PMA) method described by Bertolini et al. (2015). One gram of seeds was crushed in $10 \mathrm{ml}$ of phosphate buffer saline and four subsamples of $200 \mu \mathrm{l}$ were made from this extract. PMA was added to two subsamples for a final concentration of $50 \mu \mathrm{M}$ then incubated in the dark at room temperature under agitation at $175 \mathrm{rpm}$ for $5 \mathrm{~min}$. After incubation, tubes were exposed to light for $10 \mathrm{~min}$ in the PMA-Lite machine. Then, DNA was extracted from the two PMA-treated subsamples and the two nontreated subsamples using the CTAB method. To quantify ' $\mathrm{Ca}$. L. solanacearum' in the carrot seed lots, these four DNA extracts for each seed lot (two PMAtreated and two nontreated extracts) were tested three times in realtime PCR along with the serial dilutions of the transformed bacteria.

Assessment of transmission of ' $\mathrm{Ca}$. $\mathrm{L}$. solanacearum' from carrot seeds to seedlings. Four different carrot seed lots of 500 seeds naturally contaminated by ' $\mathrm{Ca}$. L. solanacearum' and two carrot seed lots of 100 seeds free of the bacterium were sown (Table 1) and thinned 17 days later to maintain one plant per pot. One hundred and eight plants from each contaminated lot and 24 plants from each healthy lot were individually labeled and grown in dimpled trays designed for tree species with taproot. All plants were maintained during the 7 months of the assay in an individual bay of an insectproof, P2-level containment glasshouse. During the germination period, the soil in the pots was kept moist. After germination, the pots were watered once or twice a week with a liquid fertilizer (Harmofulgur 10.10.10). The temperature of the glasshouse was maintained at $24^{\circ} \mathrm{C} \pm$ $5^{\circ} \mathrm{C}, 45$ to $60 \%$ of relative humidity, and under natural daylight conditions. To monitor the absence of insect vectors, a one-month fallow period was observed in the glasshouse before the assay and yellow sticky traps were installed every $2 \mathrm{~m}$ and checked once or twice a week. Starting two months following sowing to the end of the trial, each carrot plant was individually sampled monthly: $1 \mathrm{~g}$ of petiole tissue was collected and analyzed using real-time PCR for ' $\mathrm{Ca}$. L. solanacearum' detection. The plants were visually inspected for symptom development during the seven months of the trial.

Table 1. Carrot seed lots used in this study and tested using real-time PCR for 'Candidatus Liberibacter solanacearum'

\begin{tabular}{|c|c|c|c|c|c|c|}
\hline \multirow[b]{2}{*}{ Lot no. } & \multirow{2}{*}{$\begin{array}{l}\text { Catalog number } \\
\text { of cultivar }\end{array}$} & \multirow{2}{*}{$\begin{array}{l}\text { Germination } \\
(\mathbf{O G})^{\mathrm{a}}\end{array}$} & \multirow{2}{*}{$\begin{array}{c}\text { Results for } \\
\text { seed-transmitted } \\
\text { pathogens }^{\mathbf{b}}\end{array}$} & \multicolumn{2}{|c|}{$\begin{array}{l}\text { Results for the detection of } \\
\text { 'Ca. L. solanacearum' }\end{array}$} & \multirow{2}{*}{$\begin{array}{c}\text { Percentage of } \\
\text { contaminated seeds }\end{array}$} \\
\hline & & & & Ct without PMA $^{c}$ & $\overline{C t}$ with PMA ${ }^{c}$ & \\
\hline A & 2031110 & $76 \%$ & Negative & 29 & 33 & $98 \%$ \\
\hline B & 2031110 & $92 \%$ & Negative & 33 & 35 & $98 \%$ \\
\hline $\mathrm{C}$ & $203 \mathrm{~A} 005$ & $91 \%$ & Negative & 28 & 30 & $100 \%$ \\
\hline $\mathrm{D}$ & 2031071 & $77 \%$ & Negative & 29 & 31 & $96 \%$ \\
\hline TS1 & 2031110 & $90 \%$ & Negative & $\mathrm{NoCt}^{\mathrm{e}}$ & $\mathrm{NoCt}^{\mathrm{e}}$ & $\mathrm{NT}^{\mathrm{f}}$ \\
\hline TS2 & 2031115 & $94 \%$ & Negative & $\mathrm{NoCt}^{\mathrm{e}}$ & $\mathrm{NoCt}^{\mathrm{e}}$ & $\mathrm{NT}^{\mathrm{f}}$ \\
\hline
\end{tabular}

${ }^{a} \mathrm{OG}=$ optimal germination testing following the rules of the International Seed Testing Association (ISTA).

${ }^{\mathrm{b}}$ Analyses consist of the detection of Alternaria dauci, A. radicina, and Xanthomonas hortorum pv. carotae. For A. dauci and A. radicina, the analyses were conducted following ISTA rules. For $X$. hortorum pv. carotae, the analyses involve a real-time PCR with primers described by Meng et al. (2004).

${ }^{c}$ Results of DNA extraction and amplification from $1 \mathrm{~g}$ of seeds; PMA = propidium monoazide.

${ }^{\mathrm{d}}$ Results obtained with 50 seeds tested individually.

${ }^{\mathrm{e}} \mathrm{NoCt}=$ no amplification, negative.

${ }^{\mathrm{f}} \mathrm{NT}=$ not tested. 


\section{Results}

Estimation of the contamination rate of carrot seed lots. Based on the statistical approach, none of the subsamples tested for the two seed lots used as negative controls (TS1 and TS2) tested positive for the bacterium (Table 2). In contrast, the subsamples of the other seed lots (A, B, C, and D) all tested positive for the bacterium with realtime PCR. To confirm these results, 50 seeds of each contaminated lot (A, B, C, and D) were individually analyzed. The percentage of contaminated seeds ranged from 96 to $100 \%$ in the contaminated seed lots (Table 1). The average $\mathrm{Ct}$ value for one seed was $29.19 \pm$ $3.15,29.32 \pm 4.71,30.16 \pm 3.39$, and $30.21 \pm 3.92$ for the A, B, C, and D seed lots, respectively.

Quantification of ' $\mathbf{C a}$. L. solanacearum'. The standard curve was established with three repetitions of a serial dilution of the cloned bacteria from $2.7 \times 10^{7}$ up to $2.7 \times 10^{1}$ cells. The standard curve showed a $\mathrm{R}^{2}=0.993$ (Fig. 1). All DNA extracts from PMA-treated and nontreated seed extracts tested positive with real-time PCR. The total number of ' $\mathrm{Ca}$. L. solanacearum' cells quantified in the seed lots ranged from $1.61 \times 10^{3}$ to $1.11 \times 10^{4}$ cells/seed (Table 3 ). When PMA was used, Ct values ranged from 26.94 to 30.07 . Thus, the number of ' $\mathrm{Ca}$. L. solanacearum' viable cells quantified in the seed lots ranged from $4.19 \times 10^{2}$ to $4.08 \times 10^{3}$ cells/seed. These results showed that between 26 and $46 \%$ of the bacteria were alive in these seed lots.

Table 2. Estimation of the contamination rate in carrot seed lots

\begin{tabular}{|c|c|c|c|c|}
\hline Lot no. & Subsampling ${ }^{\mathbf{a}}$ & $\begin{array}{l}\text { No. of positive } \\
\text { samples }\end{array}$ & $\begin{array}{l}\text { MPN in } \\
100 \text { seeds }^{b}\end{array}$ & $\begin{array}{c}\text { Confidence } \\
\text { interval }^{\mathbf{b}}\end{array}$ \\
\hline \multirow[t]{3}{*}{$\overline{\mathrm{A}}$} & $1 \times 50$ seeds & 1 & $>161$ & 39 to $>450$ \\
\hline & $5 \times 10$ seeds & 5 & & \\
\hline & $5 \times 1$ seed & 5 & & \\
\hline \multirow[t]{3}{*}{ B } & $1 \times 50$ seeds & 1 & $>161$ & 39 to $>450$ \\
\hline & $5 \times 10$ seeds & 5 & & \\
\hline & $5 \times 1$ seed & 5 & & \\
\hline \multirow[t]{3}{*}{$\mathrm{C}$} & $1 \times 50$ seeds & 1 & $>161$ & 39 to $>450$ \\
\hline & $5 \times 10$ seeds & 5 & & \\
\hline & $5 \times 1$ seed & 5 & & \\
\hline \multirow[t]{3}{*}{$\mathrm{D}$} & $1 \times 50$ seeds & 1 & $>161$ & 39 to $>450$ \\
\hline & $5 \times 10$ seeds & 5 & & \\
\hline & $5 \times 1$ seed & 5 & & \\
\hline \multirow[t]{3}{*}{ TS1 } & $1 \times 50$ seeds & 0 & $<1$ & $<0.5$ \\
\hline & $5 \times 10$ seeds & 0 & & \\
\hline & $5 \times 1$ seed & 0 & & \\
\hline \multirow[t]{3}{*}{ TS2 } & $1 \times 50$ seeds & 0 & $<1$ & $<0.5$ \\
\hline & $5 \times 10$ seeds & 0 & & \\
\hline & $5 \times 1$ seed & 0 & & \\
\hline
\end{tabular}

${ }^{a}$ Number of lots each containing a defined number of seeds.

${ }^{\mathrm{b}}$ Most probable number (MPN) and associated confidence interval were obtained from reference tables (Swaroop 1951).
Assessment of transmission of ' $\mathrm{Ca}$. L. solanacearum' from carrot seeds to seedlings. No typical symptoms were observed during the assay and no insects were captured on sticky traps. None of the plants from the TS1 and TS2 seed lots tested positive during the 6 months of the assay. In the second month after sowing, none of the carrots from the A, B, C, and D seed lots tested positive. During the following months, inconclusive results were obtained for one carrot in month 3 , five carrots in month 4 , two carrots in month 5 and one carrot in month 6 on a total of 432 carrots tested individually and monthly (Table 4). The Ct values obtained with the undiluted DNA extracts for these samples ranged from 35.73 to 43.07. None of the samples involved tested positive for more than one period. For example, the suspicious plant from month 5 in lot A was negative in month 6 and the three suspicious carrots in month 4 were negative in month 5. To confirm the contamination of the plants or to verify the hypothesis of contamination during PCR analysis, the analyses were conducted again on these plants on the stored DNA extracts and on the stored crude extract of the suspected positive samples. New sampling of the crown of these suspected plants was also carried out in month 7 . Only three DNA extracts on nine plants tested positive (Table 5). All the conserved crude extracts and all the resampling on these nine carrot plants were negative for the bacterium.

\section{Discussion}

'Candidatus Liberibacter solanacearum' was detected in commercial carrot seed lots in Spain and in carrot fields for seed production in France, suggesting that the pathogen can be seed-transmitted (Bertolini et al. 2015; Loiseau et al. 2014). In their assay on seed transmission, Bertolini et al. (2015) uncovered between 12 to $42 \%$ of positive seedlings. In contrast, in different agronomic conditions, an assay conducted in another laboratory on the same three seed lots failed to demonstrate the transmission of ' $\mathrm{Ca}$. L. solanacearum' by carrot seeds (Loiseau et al. 2017). In the present study, seed lots contaminated by viable ' $C a$. L. solanacearum' were sown and the carrots derived from these seedlings were monitored for 7 months in temperate conditions to reproduce the growing conditions of Bertolini et al. (2015). However, no transmission of ' $\mathrm{Ca}$. L. solanacearum' by carrot seeds was observed.

In the present study, the contamination rate of the seeds lots used ranged from 96 to $100 \%$. This is higher than the level of contamination in the seeds lots used in the previous studies, where it was estimated to range between 47 and 94\% (Bertolini et al. 2015). Between 26 and $46 \%$ of ' $\mathrm{Ca}$. L. solanacearum' detected in these seed lots were viable, which is higher than the $5 \%$ of viable cells in the seeds lots used in the previous studies by Bertolini et al. 2015. Due to the unculturable nature of ' $\mathrm{Ca}$. L. solanacearum', the PMA test used for both assays may lead to an overestimation or underestimation of the actual number of viable cells in the extracts as previously demonstrated (Cangelosi and Meschke 2014). However, the results obtained in the present study can be compared with the results of the previous study
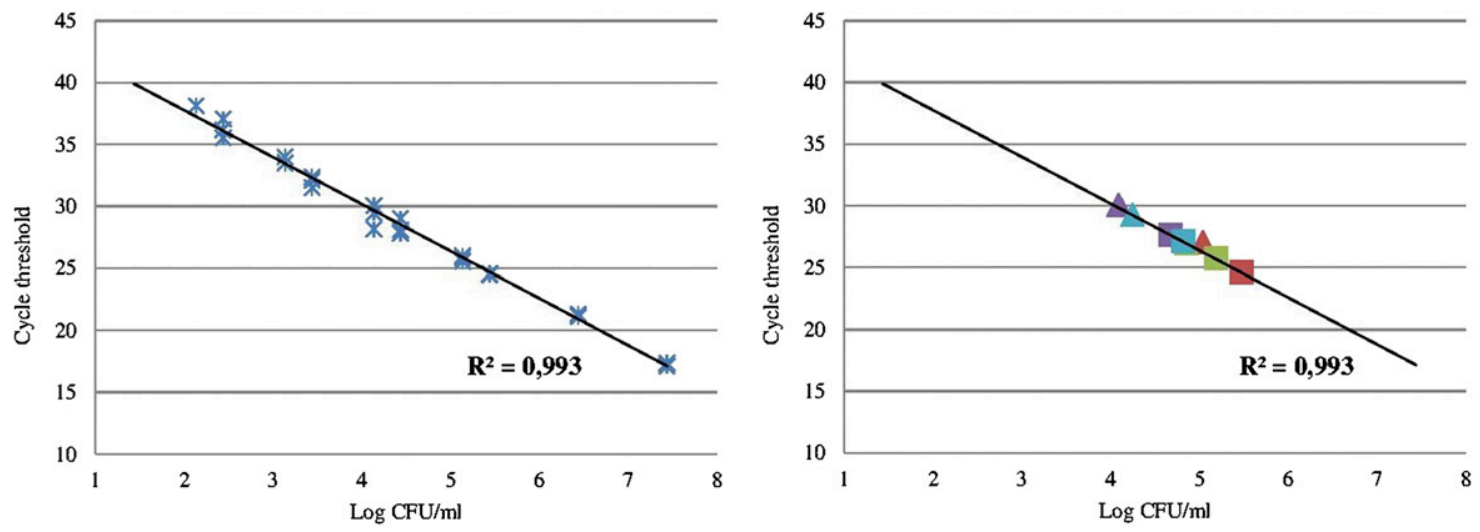

Fig. 1. On the left, standard curve obtained with the serial dilution of the transformed bacteria $(x)$ and on the right, average of the results obtained for the DNA extracts from the $A$ (red), B (green), C (purple), and D (blue) seeds lot. Nontreated extracts, -; PMA-treated extracts, $\mathbf{\Delta}$ 
on 'Ca. L. solanacearum' by Bertolini et al. 2015 because it was carried out in the same experimental conditions. Too much or too little inoculum of many pathogens can result in nontransmission of the disease (Maude 1996). Here, the seed lots were highly contaminated and had higher proportion of viable bacteria than in previous studies (Bertolini et al. 2015; Loiseau et al. 2017). The nontransmission of a seedtransmitted disease in the case of an abundant inoculum is linked to the reduction of the viability of the seed (Maude, 1996). In this study, at least $96 \%$ of the seeds were contaminated and those seeds have been chosen for a satisfactory rate of germination.

Maude (1996) provides details on the environmental factors affecting disease transmission by seed. Temperature, moisture, light, and $\mathrm{pH}$ are the most important environmental factors that influence the contamination of plants. For some fungi and bacteria, an increase in moisture during germination can increase transmission rates. For some viruses, increases in temperature can decrease the rate of transmission by seed from 100 to $0 \%$. There is no detail available in Bertolini et al. (2015) on moisture or temperature used during their assay. In this study, moisture was not controlled except during the germination of the seeds, when soil was kept moist until cotyledons appeared at the surface of the soil. According to Munyaneza et al. (2012a), temperatures between 12 and $32^{\circ} \mathrm{C}$ allow multiplication of ' $\mathrm{Ca}$. L. solanacearum' and development of Zebra Chip symptoms in potatoes under controlled laboratory conditions. Thus, the temperature under which the present study was conducted (mean value at $24^{\circ} \mathrm{C}$ ) was conducive to the multiplication of the bacterium.

Both host and pathogen genotypes affect the capacity for seed transmissibility of a pathogen in a host. For a given pathogen, the capability for seed transmission varies greatly with different species or even varieties and cultivars of a particular host plant. However, this variability has been correlated with the susceptibility of the mother plant of the seed (Maude 1996). In this study, the high rate of contamination of the seed lots proves that the mother plants of the seed were all susceptible to ' $\mathrm{Ca}$. L. solanacearum'. Only one seed lot used during the study by Bertolini et al. (2015) was identified as haplotype E. This seed lot gave rise to the symptomatic seedlings. The three other seed lots used in the previous studies (Bertolini et al. 2015; Loiseau et al. 2017) were contaminated with haplotype D as were the seeds lots used in this study (data not shown). Even if the five haplotypes are not yet known to elicit biological differences (Munyaneza 2015),

Table 3. Results of the quantification of 'Candidatus Liberibacter solanacearum' cells in carrot seed lots

\begin{tabular}{lccccc}
\hline Lot no. & Treatment & Mean Ct value \pm SD & Equivalent in CFUa/ml \pm SD & Number of bacteria/seed & Percentage of viable bacteria \\
\hline A & none & $24.63 \pm 0.48$ & $2.96 \times 10^{5} \pm 8.42 \times 10^{4}$ & $1.11 \times 10^{4}$ & $36.75 \%$ \\
& PMA & $27.04 \pm 1.95$ & $1.09 \times 10^{5} \pm 9.45 \times 10^{4}$ & $4.08 \times 10^{3}$ & $45.90 \%$ \\
B & none & $25.78 \pm 0.7$ & $1.53 \times 10^{5} \pm 6.16 \times 10^{4}$ & $5.45 \times 10^{3}$ & $2.50 \times 10^{3}$ \\
\\
C & PMA & $26.94 \pm 0.14$ & $7.04 \times 10^{4} \pm 6.07 \times 10^{3}$ & $1.61 \times 10^{3}$ & $25.99 \%$ \\
& none & $27.61 \pm 0.09$ & $4.70 \times 10^{4} \pm 2.66 \times 10^{3}$ & $4.19 \times 10^{2}$ & $2.15 \times 10^{3}$ \\
D & PMA & $30.07 \pm 1$ & $1.22 \times 10^{4} \pm 6.73 \times 10^{3}$ & $8.44 \times 10^{2}$ & - \\
& none & $27.13 \pm 0.55$ & $6.55 \times 10^{4} \pm 2.12 \times 10^{4}$ & - & - \\
TS1 & PMA & $29.24 \pm 0.19$ & $1.76 \times 10^{4} \pm 1.97 \times 10^{3}$ & - & - \\
TS2 & none & NoCt & - & - & - \\
\hline
\end{tabular}

${ }^{\mathrm{a}} \mathrm{CFU}=$ colony forming unit.

Table 4. Frequency of detection of 'Candidatus Liberibacter solanacearum' in carrot plants as a function of sampling dates. Results of the detection of ' $C a$. L. solanacearum' by real-time PCR (number of positive plant/total number of analyzed plants)

\begin{tabular}{|c|c|c|c|c|c|}
\hline \multirow[b]{2}{*}{ Lot no. } & \multicolumn{5}{|c|}{ Date of sampling (MM/DD) (month after sowing) } \\
\hline & 05/19 (month 2) & $06 / 18$ (month 3) & 07/17 (month 4) & 08/14 (month 5) & $09 / 14$ (month 6) \\
\hline $\mathrm{A}$ & $0 / 108$ & $0 / 108$ & $(3)^{a} / 108$ & $(1) / 108$ & $0 / 108$ \\
\hline $\mathrm{B}$ & $0 / 108$ & $0 / 108$ & $(2) / 108$ & $0 / 108$ & $0 / 108$ \\
\hline $\mathrm{C}$ & $0 / 108$ & $(1) / 108$ & $0 / 108$ & $0 / 108$ & $0 / 108$ \\
\hline $\mathrm{D}$ & $0 / 108$ & $0 / 108$ & $0 / 108$ & $(1) / 108$ & $(1) / 108$ \\
\hline TS1 & $0 / 24$ & $0 / 24$ & $0 / 24$ & $0 / 24$ & $\mathrm{nt}^{\mathrm{b}}$ \\
\hline TS2 & $0 / 24$ & $0 / 24$ & $0 / 24$ & $0 / 24$ & $\mathrm{nt}$ \\
\hline
\end{tabular}

a Parentheses (\#) indicate inconclusive result; see Table 5 for details.

${ }^{b} \mathrm{nt}=$ not tested.

Table 5. Complementary results of the detection of 'Candidatus Liberibacter solanacearum' on the carrot plants that gave inconclusive results

\begin{tabular}{|c|c|c|c|c|c|c|}
\hline \multirow[b]{2}{*}{ Lot no. } & \multirow[b]{2}{*}{ Plant no. } & \multirow[b]{2}{*}{ Month of the ambiguous result } & \multirow[b]{2}{*}{ Initial Ct value $^{a}$} & \multicolumn{3}{|c|}{ Ct value for } \\
\hline & & & & Stored DNA extract & Stored crushed sample & Sample from month 7 \\
\hline \multirow[t]{4}{*}{$\bar{A}$} & 13 & 5 & 43.07 & $\mathrm{NoCt}^{\mathrm{c}}$ & $\mathrm{NoCt}$ & $\mathrm{NoCt}$ \\
\hline & 98 & 4 & 37.41 & $\mathrm{NoCt}$ & $\mathrm{NoCt}$ & $\mathrm{NoCt}$ \\
\hline & 99 & 4 & 37.02 & 36.73 & $\mathrm{NoCt}$ & $\mathrm{NoCt}$ \\
\hline & 100 & 4 & $37.26^{\mathrm{b}}$ & 35.69 & $\mathrm{NoCt}$ & $\mathrm{NoCt}$ \\
\hline \multirow[t]{2}{*}{ B } & 15 & 4 & 37.8 & $\mathrm{NoCt}$ & $\mathrm{NoCt}$ & $\mathrm{NoCt}$ \\
\hline & 81 & 4 & 41.19 & 36.13 & $\mathrm{NoCt}$ & $\mathrm{NoCt}$ \\
\hline $\mathrm{C}$ & 64 & 3 & 38.63 & $\mathrm{NoCt}$ & $\mathrm{NoCt}$ & $\mathrm{NoCt}$ \\
\hline \multirow[t]{2}{*}{$\mathrm{D}$} & 41 & 6 & 35.73 & $\mathrm{NoCt}$ & $\mathrm{NoCt}$ & $\mathrm{NoCt}$ \\
\hline & 64 & 5 & 39.77 & $\mathrm{NoCt}$ & $\mathrm{NoCt}$ & $\mathrm{NoCt}$ \\
\hline
\end{tabular}

${ }^{a} \mathrm{Ct}$ values correspond to the obtained values with undiluted DNA extracts. If no precision was added, there was no amplification with the 1:10 diluted DNA extract.

${ }^{\mathrm{b}} \mathrm{Ct}$ value for the 1:10 diluted DNA extract is 40.51 .

${ }^{\mathrm{c}} \mathrm{NoCt}=$ no amplification; negative. 
it is possible that the haplotype $\mathrm{E}$ has an effect on symptoms. However, it cannot have an effect on vertical transmission because in the study by Bertolini et al. (2015), both bacterium haplotypes led to transmission.

Given the fact that ' $\mathrm{Ca}$. L. solanacearum' is not yet culturable, the most relevant technique to detect the bacterium is based on PCR. To date, several assays have been developed for the detection of ' $\mathrm{Ca}$. L. solanacearum' (Beard et al. 2013; Li et al. 2009; Liefting et al. 2009a; Nissinen et al. 2014; Ravindran et al. 2011; Ravindran et al. 2012; Teresani et al. 2014; Wen et al. 2009; Wen et al. 2013). In a comparison of detection methods, Teresani et al. (2014) showed the detection limit of the real-time PCR of Li et al. (2009) to be below a Ct-value of 35 and equivalent to the real-time PCR they developed. Nevertheless, when positive results near this detection limit (Ct greater than 35), no completely independent second test is available to confirm those positive results. For this reason, the detection of the bacterium was repeated on the carrots that gave inconclusive results. No positive results were obtained on the stored crude extracts or on new samples of the same plants. Therefore, the nine inconclusive results obtained during the study are considered as microcontaminations during DNA extraction or amplification despite clear positive and negative controls in both steps.

The overall results of the present study failed to demonstrate the transmission of ' $\mathrm{Ca}$. L. solanacearum' from carrot seeds to daughter plants. Reports of seed transmission of phloem- or xylem-limited pathogens are very rare and, most of the time, results obtained in these studies have not been reproducible, or have been reproduced only with difficulty (Della Coletta-Filho et al. 2014; Hartung et al. 2014; Lapierre \& Signoret 2004). Some reports suggest putative seed transmission of phloem- or xylem-limited pathogens. For example, given the fact that phytoplasmas can be detected in seeds (Cordova et al. 2003; Nečas et al. 2008), there are suspicions that phytoplasma diseases can be transmitted by seeds. Nevertheless, no reliable or reproducible study has confirmed this hypothesis (Dickinson et al. 2013). Similarly, in the first studies on citrus seed transmission of 'Candidatus Liberibacter asiaticus', the possibility of vertical transmission of this bacterium was debated (Tatineni et al. 2008; Tirtawidjaja 1981). However, intensive research by Hartung et al. (2010) has never uncovered any typical symptoms of Huanglongbing nor positive tests for ' $\mathrm{Ca}$. L. asiaticus' during the three years of trials on 723 seedlings grown from seeds collected from infected citrus trees. Currently, there is still no evidence of its transmission through citrus seed. Previous reports of the transmission of the pathogen by seed have never been confirmed.

For other obligate parasites such as viruses, Mink (1993) reviewed information on seed-transmitted viruses and provided details on 14 viruses erroneously listed as seed-transmitted for various reasons including the lack of reproducibility of the initial assay. Furthermore, viruses that are restricted to vascular tissues have not been shown to be seed transmitted (Baker 1972). From this observation, for future reports of seed-transmitted viruses, Sastry (2013) proposed that the demonstration of the seed transmission must be accompanied by a demonstration that the virus can be transmitted from suspected seedlings using insect vectors. Because the liberibacters are nonculturable pathogens and are naturally transmitted by vectors, any future reports on seed transmission should follow this rule.

Since 2010, various outbreaks of ' $\mathrm{Ca}$. L. solanacearum' in carrot crops have been reported in several countries in Europe and North Africa. For this reason, Teresani et al. (2014) suggested that the bacteria are transmitted vertically through seed, leading to numerous questions regarding the distribution and spread of ' $\mathrm{Ca}$. L. solanacearum' on carrot crops worldwide. France is one of the leading producers and suppliers of carrot seeds in the world (Laurent et al. 2014). Indeed, carrots are produced everywhere in the world (Simon 2000) but there are only reports of this disease on apiaceous in Europe and North Africa. Moreover, only ' $\mathrm{Ca}$. L. solanacearum' haplotypes D and E are found in France (Hajri et al. 2017). In Scandinavia and in Germany, only haplotype $\mathrm{C}$ occurs (Munyaneza et al. 2015; Nelson et al. 2011; Nelson et al. 2013;) and carrot seeds are not produced in these countries. Consequently, the likely origin of the contamination must have arisen elsewhere than in seed. Furthermore, the mother seeds of the seed lots used in the previous studies by
Loiseau et al. (2017) were not contaminated by ' $\mathrm{Ca}$. L. solanacearum'. Following the results of the present study and the observations on carrot disease distribution, seeds are not likely to be the initial source of contamination by ' $\mathrm{Ca}$. L. solanacearum'. Further investigations are needed to better understand the epidemiology of this bacterium in carrot crops. Recent studies have demonstrated the active and efficient role of the psyllids Trioza apicalis (Nissinen et al. 2014) and Bactericera trigonica (Antolínez et al. 2017a, b) in the transmission of the bacterium. More studies are needed to better understand the biology of those psyllids and their distribution in regions where ' $\mathrm{Ca}$. $\mathrm{L}$. solanacearum' occurs. The presence of symptomatic or asymptomatic cultivated plants or weeds capable of acting as a reservoir in the vicinity of carrot crops must also be explored.

' $\mathrm{Ca}$. L. solanacearum' is not transmitted through true seed from infected solanaceous plants (Munyaneza, 2012). This study confirmed the results obtained during our first experiment (Loiseau et al. 2017) despite using the growing conditions described by Bertolini et al. (2015). No consistent results were obtained to demonstrate that ' $\mathrm{Ca}$. L. solanacearum' can be vertically transmitted from seed to seedlings in our laboratory. If the transmission of ' $\mathrm{Ca}$. L. solanacearum' by carrot seed is at all possible, it is probably rare and difficult to reproduce.

\section{Acknowledgments}

We thank Marie-Agnès Jacques (INRA, UMR 1345 Institut de Recherche en Horticulture et Semences (IRHS), 49071 Beaucouzé, France) for critical reading of the manuscript.

\section{Literature Cited}

Alfaro-Fernández, A., Cebrián, M. C., Villaescusa, F. J., Hermoso de Mendoza, A., Ferrándiz, J. C., Sanjuán, S., and Font, M. I. 2012a. First report of 'Candidatus Liberibacter solanacearum' in carrots in mainland Spain. Plant Dis. 96:582.

Alfaro-Fernández, A., Siverio, F., Cebrián, M. C., Villaescusa, F. J., and Font, M. I. 2012b. 'Candidatus Liberibacter solanacearum' associated with Bactericera trigonica-affected carrots in the Canary Islands. Plant Dis. 96:581.

Antolinez, C., Fereres, A., and Moreno, A. 2017b. Risk assessment of 'Candidatus Liberibacter solanacearum'transmission by the psyllids Bactericera trigonica and B. tremblayi from Apiaceae crops to potato. Sci. Rep.: 7:45534.

Antolínez, C. A., Fereres, A., and Moreno, A. 2017a. Sex-specific probing behaviour of the carrot psyllid Bactericera trigonica and its implication in the transmission of 'Candidatus Liberibacter solanacearum'. Eur. J. Plant Pathol. 147:627-637.

Baker K. F. 1972. Seed pathology. Pages 317-416 in: Seed Biology, Vol. 2. Academic Press, New York.

Beard, S. S., Pitman, A. R., Kraberger, S., and Scott, IaW. 2013. SYBR Green real-time quantitative PCR for the specific detection and quantification of 'Candidatus Liberibacter solanacearum' in field samples from New Zealand. Eur. J. Plant Pathol. 136:203-215.

Bertolini, E., Teresani, G. R., Loiseau, M., Tanaka, F. A. O., Barbé, S., Martínez, C. Gentit, P., López, M. M., and Cambra, M. 2015. Transmission of 'Candidatus Liberibacter solanacearum' in carrot seeds. Plant Pathol. 64:276-285.

Bové, J. M. 2006. Huanglongbing: A destructive, newly-emerging, century-old disease of citrus. J. Plant Pathol.:88:7-37.

Cangelosi, G. A., and Meschke, J. S. 2014. Dead or alive: Molecular assessment of microbial viability. Appl. Environ. Microbiol. 80:5884-5891.

Cordova, I., Jones, P., Harrison, N. A., and Oropeza, C. 2003. In situ PCR detection of phytoplasma DNA in embryos from coconut palms with lethal yellowing disease. Mol. Plant Pathol. 4:99-108.

Della Coletta-Filho, H., Carvalho, S. A., Silva, L. F. C., and Machado, M. A. 2014. Seven years of negative detection results confirm that Xylella fastidiosa, the causal agent of CVC, is not transmitted from seeds to seedlings. Eur. J. Plant Pathol. 139:593-596.

Dickinson, M., Tuffen, M., and Hodgetts, J. 2013. The phytoplasmas: An introduction. Methods Mol. Biol. 938:1-14.

EPPO. 2015. Report 2015/029: First report of 'Candidatus Liberibacter solanacearum' in Austria. EPPO, Paris. Online: https://gd.eppo.int/reporting/article-4455

EPPO. 2017. Report 2017/020: First report of 'Candidatus Liberibacter solanacearum' on carrots in Israel. EPPO, Paris. Online: https://gd.eppo.int/ reporting/article-5988

Hajri, A., Loiseau, M., Cousseau-Suhard, P., Renaudin, I., and Gentit, P. 2017. Genetic characterization of 'Candidatus Liberibacter solanacearum' haplotypes associated with apiaceous crops in France. Plant Dis. 101:1383-1390.

Hartung, J., Halbert, S., Pelz-Stelinski, K., Brlansky, R., Chen, C., and Gmitter, F. 2010. Lack of evidence for transmission of 'Candidatus Liberibacter asiaticus' through citrus seed taken from affected fruit. Plant Dis. 94:1200-1205.

Hartung, J., Nian, S., Lopes, S., Ayres, A., and Brlansky, R. 2014. Lack of evidence for transmission of Xylella fastidiosa from infected sweet orange seed. J. Plant Pathol. 96:497-506.

Jagoueix, S., Bove, J.-M., and Garnier, M. 1994. The phloem-limited bacterium of greening disease of citrus is a member of the $\alpha$ subdivision of the Proteobacteria. Int. J. Syst. Bacteriol. 44:379-386. 
Lapierre, H., and Signoret, P.-A. 2004. Viruses and virus diseases of Poaceae (Gramineae). Quae Versailles, France.

Laurent, E., Daviot, D., and Lesprit, E. 2014. France, a leading producer for carrot seeds in the world. Proc. of the Carrot and Other Apiacae Int. Symp., Angers, France.

Li, W., Abad, J. A., French-Monar, R. D., Rascoe, J., Wen, A., Gudmestad, N. C., Secor, G. A., Lee, I. M., Duan, Y., and Levy, L. 2009. Multiplex real-time PCR for detection, identification and quantification of 'Candidatus Liberibacter solanacearum' in potato plants with zebra chip. J. Microbiol. Methods 78: 59-65.

Liefting, L. W., Sutherland, P. W., Ward, L. I., Paice, K. L., Weir, B. S., and Clover, G. R. G. 2009a. A new 'Candidatus Liberibacter' species associated with diseases of solanaceous crops. Plant Dis. 93:208-214.

Liefting, L. W., Weir, B. S., Pennycook, S. R., and Clover, G. R. G. 2009b. 'Candidatus Liberibacter solanacearum', associated with plants in the family Solanaceae Int. J. Syst. Evol. Microbio. 59:2274-2276.

Loiseau, M., Garnier, S., Boirin, V., Merieau, M., Leguay, A., Renaudin, I., Renvoisé, J. P., and Gentit, P. 2014. First Report of 'Candidatus Liberibacter solanacearum' in carrot in France. Plant Dis. 98:839.

Loiseau, M., Renaudin, I., Cousseau-Suhard, P., Poliakoff, F., and Gentit, P. 2017. Transmission tests of 'Candidatus Liberibacter solanacearum' by carrot seeds. Acta Hortic.: 41-46.

Maude, R. 1996. Seedborne diseases and their control: Principles and practice. CAB Int.,

Meng, X., Umesh, K., Davis, R., and Gilbertson, R. 2004. Development of PCRbased assays for detecting Xanthomonas campestris pv. carotae, the carrot bacterial leaf blight pathogen, from different substrates. Plant Dis. 88:1226-34.

Mink, G. I. 1993. Pollen and seed-transmitted viruses and viroids. Annu. Rev. Phytopathol. 31:375-402.

Munyaneza, J. 2012. Zebra chip disease of potato: Biology, epidemiology, and management. Am. J. Potato Res.: 1-22.

Munyaneza, J. 2015. Zebra chip disease, Candidatus Liberibacter, and potato psyllid: A global threat to the potato industry. Am. J. Potato Res. 92:230-235.

Munyaneza, J. E., Crosslin, J. M., and Upton, J. E. 2007. Association of Bactericera cockerelli (Homoptera: Psyllidae) with "zebra chip", a new potato disease in southwestern United States and Mexico. J. Econ. Entomol. 100:656-663.

Munyaneza, J. E., Fisher, T. W., Sengoda, V. G., and Garczynski, S. F. 2010b. First report of 'Candidatus Liberibacter solanacearum' associated with psyllid-affected carrots in Europe. Plant Dis. 94:639.

Munyaneza, J. E., Fisher, T. W., Sengoda, V. G., Garczynski, S. F., Nissinen, A., and Lemmetty, A. 2010a. Association of "Candidatus Liberibacter solanacearum" with the psyllid Trioza apicalis (Hemiptera: Triozidae) in Europe. J. Econ. Entomol. 103: 1060-1070

Munyaneza, J. E., Sengoda, V. G., Buchman, J. L., and Fisher, T. W. 2012a. Effects of temperature on 'Candidatus Liberibacter solanacearum' and zebra chip potato disease symptom development. Plant Dis. 96:18-23.

Munyaneza, J. E., Sengoda, V. G., Stegmark, R., Arvidsson, A. K., Anderbrant, O., Yuvaraj, J. K., Rämert, B., and Nissinen, A. 2012b. First report of "Candidatus Liberibacter solanacearum" associated with psyllid-affected carrots in Sweden. Plant Dis. 96:453.

Munyaneza, J. E., Sengoda, V. G., Sundheim, L., and Meadow, R. 2012c. First report of "Candidatus Liberibacter solanacearum" associated with psyllidaffected carrots in Norway. Plant Dis. 96:454.

Munyaneza, J. E., Swisher, K. D., Hommes, M., Willhauck, A., Buck, H., and Meadow, R. 2015. First report of 'Candidatus Liberibacter solanacearum' associated with psyllid-infested carrots in Germany. Plant Dis. 99:1269.

Murray, M. G., and Thompson, W. F. 1980. Rapid isolation of high molecular weight plant DNA. Nucleic Acids Res. 8:4321-4325.
Nečas, T., Mašková, V., Krška, B., 2008. The possibility of ESFY phytoplasma transmission through flowers and seeds. ISHS Acta Horticultura 781.

Nelson, W. R., Fisher, T. W., and Munyaneza, J. E. 2011. Haplotypes of "Candidatus Liberibacter solanacearum" suggest long-standing separation. Eur. J. Plant Pathol. 130:5-12

Nelson, W. R., Sengoda, V. G., Crosslin, J. M., Alfaro-Fernández, A. O., Font, M. I. and Munyaneza, J. E. 2013. A new haplotype of "Candidatus Liberibacter solanacearum" in the Mediterranean region. Eur. J. Plant Pathol. 135:633-639.

Nissinen, A. I., Haapalainen, M., Jauhiainen, L., Lindman, M., and Pirhonen, M 2014. Different symptoms in carrots caused by male and female carrot psyllid feeding and infection by 'Candidatus Liberibacter solanacearum'. Plant Pathol. 63:812-820.

Noble, M. 1957: The transmission of plant pathogens by seed. Pages 81-85 in: Biological Aspects of Transmission of Disease. Oliver and Boyd, Edinburgh, UK

Pitman, A. R., Drayton, G. M., Kraberger, S. J., Genet, R. A., and Scott, I. A. W. 2011 Tuber transmission of 'Candidatus Liberibacter solanacearum' and its association with zebra chip on potato in New Zealand. Eur. J. Plant Pathol. 129:389-398.

Ravindran, A., Levy, J., Pierson, E., and Gross, D. C. 2011. Development of primers for improved PCR detection of the potato Zebra Chip pathogen, 'Candidatus Liberibacter solanacearum'. Plant Dis. 95:1542-6.

Ravindran, A., Levy, J., Pierson, E., and Gross, D. C. 2012. Development of a loop-mediated isothermal amplification procedure as a sensitive and rapid method for detection of'candidatus Liberibacter solanacearum'in potatoes and Psyllids. Phytopathology 102:899-907.

Sastry, K. S. 2013. Seed-borne plant virus diseases. Springer India, New Delhi.

Secor, G. A., Rivera-Varas, V., Abad, J. A., Lee, I. M., Clover, G. R. G., Liefting, L. W., Li, X., and De Boer, S. H. 2009. Association of 'Candidatus Liberibacter solanacearum' with zebra chip disease of potato established by graft and psyllid transmission, electron microscopy, and PCR. Plant Dis. 93:574-583.

Simon, P. W. 2000. Domestication, historical development, and modern breeding of carrot. Plant Breed. Rev. 19:157-190.

Swaroop, S. 1951. The range of variation of the most probable number of organisms estimated by the dilution method. Indian J. Med. Res. 39:107-34

Tahzima, R., Maes, M., Achbani, E. H., Swisher, K. D., Munyaneza, J. E., and De Jonghe, K. 2014. First Report of 'Candidatus Liberibacter solanacearum' on Carrot in Africa. Plant Dis. 98:1426.

Tahzima, R., Massart, S., Achbani, E. H., Munyaneza, J. E., and Ouvrard, D. 2017. First report of 'Candidatus liberibacter solanacearum' associated with the psyllid Bactericera trigonica Hodkinson on carrots in Northern Africa. Plant Dis. 101:242.

Tatineni, S., Sagaram, U. S., Gowda, S., et al. 2008. In planta distribution of 'Candidatus Liberibacter asiaticus' as revealed by polymerase chain reaction (PCR) and real-time PCR. Phytopathology 98:592-9.

Teresani, G. R., Bertolini, E., Alfaro-Fernández, A., Martínez, C., Tanaka, F. A. O., Kitajima, E. W., Roselló, M., Sanjuán, S., Ferrándiz, J. C., López, M. M., Cambra, M., and Font, M. I. 2014. Association of 'Candidatus Liberibacter solanacearum' with a vegetative disorder of celery in Spain and development of real-time PCR method for its detection. Phytopathology 104:804-811.

Tirtawidjaja, S. 1981. Insect, dodder and seed transmission of citrus vein phloem degeneration (CVPD). Pages 469-471 in: Proc. of the 4th Int. Congress on Citrus, Int. Soc. of Citriculture, Riverside, CA.

Wen, A., Johnson, C., and Gudmestad, N. C. 2013. Development of a PCR assay for the rapid detection and differentiation of 'Candidatus Liberibacter solanacearum' haplotypes and their spatiotemporal distribution in the United States. Am. J. Potato Res. 90:229-236.

Wen, A., Mallik, I., Alvarado, V. Y., Pasche, J. S., Wang, X., Li, W., Levy, L., Lin, H., Scholthof, H., Mirkov, E., Rush, C. M., and Gudmestad, N. C. 2009 Detection, distribution, and genetic variability of 'Candidatus Liberibacter' species associated with the zebra complex disease of potato in the North America. Plant Dis. 93:1102-1115. 